\title{
PRIMARY SOURCE
}

\section{Two Papal Bulls of 6 March 1255, Issued by Alexander IV for King Mindaugas of Lithuania}

\section{5, March 6, Naples,}

Pope Alexander IV grants the king of Lithuania (Mindaugas) the right to have his son crowned by a Latin bishop of his preference.

B: Vatican City, Archivio Segreto Vaticano, Registrum Vaticanum 24, fo. $27^{\mathrm{v}}$.

Pub.: Vetera Monumenta Poloniae et Lithuaniae ... ex tabulariis Vaticanis deprompta, I (1217-1409), ed. A. Theiner (Rome, 1860), No. 123, p. 60-61. Theiner publishes both documents under the same heading.

Reg.: Preussisches Urkundenbuch. Politische Abtheilung, I.1, ed. Philippi, Wölky (Königsberg, 1882), No. 310, p. 229

${ }^{1}$.. Illustri Regi Lectovie ${ }^{2}$

Catholice fidei cultum longius latiusque per orbem diffundi continue super omnia cordis nostri desiderabilia cupientes, ad eiusdem augmentum fidei vigili sedulaque sollercia non cessamus intendere ac, ut iuxta nostri desiderii plenitudinem valeat provenire, totius diligentie studium, excusso in hac parte cuiuslibet negligentie otio, adhibemus, augmentum ipsum per nos ac alios omni ope $\mathrm{ac}^{3}$ opera, prout ex alto ${ }^{4}$ conceditur, assidue
To .., the illustrious king of Lithuania.

Wishing above all the desires of our heart that the cultivation of the Catholic Faith spread ever more far and wide throughout the world, we do not cease striving for the augmentation of the same Faith with vigilant and sedulous care; and in order for the fullness of our desire to come forth we maintain efforts of complete diligence, denying ourselves the leisure of any negligence in this matter, procuring

\footnotetext{
${ }^{1}$ a: Alexander episcopus etc. carissimo in Christo filio nostro added by editor

2 a: salutem etc. added by editor

${ }^{3}$ a: et

${ }^{4} \mathrm{~B}$ : exalto
} 
procurando. Hinc est, quod cum, this growth [in the faith] assidusicut te intimante nobis accepimus, ously ourselves and through othtu divinitus inspiratus de paganice ers with all effort and labour, in so cecitatis errore ad viam vite, que far as we are granted [to do] this Christus est, baptismatis renatus from on high. Therefore, since, as unda redieris et Deo vivo ac vero placere studeas sub religionis observantia christiane, nos, de hoc multo concepto gaudio volentes te in huiusmodi fide congruis roborare favoribus et condignis gratiis confovere, tuis supplicationibus inclinati, excellentie tue, ut quem mallueris latinum episcopum, pacem et communionem apostolice sedis habentem, tibi advocare liceat, qui dilectum filium, nobilem virum ..., natum tuum, ad honorem Dei et sancte Romane ecclesie in Regem Lectovie auctoritate nostra coronet, tenore presentium indulgemus. Nulli etc. nostre concessionis etc.. Datum Neapoli .ii. non. Martii. anno .I ${ }^{\circ}$. we have learned through your intimations, you have been divinely inspired and have returned through the waters of baptism from the errors of pagan blindness to the Way of Life, that is Christ, and are striving through observance of Christian Religion to please the Living and True God, we through these presents grant your Excellency [the right] to summon a Latin bishop of your preference, who is in peace and communion with the Apostolic See, to crown by our authority [our] beloved son, the noble man $[\ldots]$, your son, as king of Lithuania to the glory of God and the holy Church of Rome. We have obtained much joy from this and wish to strengthen you in the faith with meet favours and bestow suitable grace upon you, for we are inclined [to grant] your requests. Let no man ... [oppose] our concession and so forth. Given at Naples the day before the nones of March in the first year [of our pontificate]. 
1255, March 6, Naples,

Pope Alexander IV grants the king of Lithuania (Mindaugas) the right to possess the lands of Rus' that have been occupied by him.

\section{Eidem}

Catholice etc. usque procurando. Cum itaque, sicut ex parte tua fuit propositum coram nobis, tu contra Regnum Russie ipsiusque habitatores in infidelitatis devio constitutos indefessa strenuitate decertans nonnullas terras ipsius Regni tue subiugaveris dicioni, nos, attendentes quod te terras habente predictas vicine paganorum et infidelium regiones de facili poterunt tuo dominio subici et acquiri cultui christiano, tuis benigne precibus annuentes, prefatas terras tibi tuisque successoribus absque catholicorum quorumlibet preiu-dicio auctoritate apostolica confirmamus etc. usque com-munimus. Nulli etc. nostre confirmationis etc. Datum ut supra.
To the Same.

Wishing above all and so forth, as far as: from on high. Therefore since, as it was laid before us, you are fighting with untiring effort against the kingdom of Rus' and the inhabitants thereof that stand in the wrong path of infidelity, when you will have subjected certain of that kingdom's lands to your rule, we, consenting graciously to your prayers, confirm with Apostolic authority the aforesaid lands as belonging to you and your successors, without harming the rights of any Catholics. For we understand that when you hold those aforesaid lands neighbouring pagan and infidel regions may easily be subjected to your rule and be won for the Christian religion. Let no man ... [oppose] our confirmation and so forth. Given as above.

Translated by S. C. Rowell

\section{THIRTEENTH-CENTURY LITHUANIA: HIGH HOPES ON DIFFICULT TERRAIN}

Darius Baronas

The Background in a Nutshell Lithuania is situated on the periphery of the Great East European Plain which has no well defined boundaries and for a long time lay open to spasmodic invasions from the Nomadic world and for some time, when Kievan 
Rus' came into being, was plied by Norse adventurers. The first mention of Lithuania is connected with the last mission of St. Bruno of Querfurt who suffered martyrdom in confinio Rusciae et Lituae in 1009. ${ }^{5}$ The written sources composed in the wake of this martyrdom betray joint interest on the part of Polish and Rus'ian rulers, Bolesław the Brave and Vladimir the Great, in reaping St. Bruno's harvest for themselves. ${ }^{6}$ And this must be viewed as an ample indication of Lithuania's ambiguous position between the emerging cultural circles of Western and Eastern Christianity. Despite episodic Rus'ian attempts to lay claim on Lithuanian territory it remained largely a 'no man's land'. Only in the course of the thirteenth century did Lithuanians come to recognize a supreme ruler, a fact that must be regarded as the first indication of a Lithuanian state.

A Leap to Prominence By the early thirteenth century Lithuanians began to mount predatory raids that reached as far as Pskov and the land of Novgorod in the north and Volyn' in the south of Rus'. The very distance and direction of Lithuanian raids show that these warriors were well familiar with communications within Rus'. By then Lithuanians were quite at home in such lands as Polotsk, and small Rus'ian principalities of Koknese and Yersika on the Dvina river. Such activities were conducive to the emergence of stronger dukes who, although not averse at eliminating outsiders from among themselves, managed to find consensus from time to time. This is best shown by the peace treaty of 1219 concluded between Lithuania and the dukes of Volyn'. 7 Lithuanian lands were represented by 21 dukes, among whom five were senior. The latter group included young Mindaugas who was lucky enough to become the first sole ruler of Lithuania.

Although Lithuanians were never sealed off tightly from influence of their neighbours, primarily Kievan Rus', the very paucity of source material available to us indicates that they maintained their barbarian way of life in some kind of backwater that was situated

5 Annales Quedlinburgenses ed. in Monumenta Germaniae Historica, Scriptores, III (Hanover, 1839), p. 80.

${ }^{6}$ D. Baronas, Paskutinè Šv. Brunono Kverfurtiečio misija geopolitikos kontekste, Lietuvos istorijos metraštis, 2001, 2, pp. 33-34. D. Baronas, Lithuania's entry into Christendom, Christianity in Lithuania by D. Baronas, L. Jovaiša, M. Paknys, E. Raila, A. Streikus, Vilnius, 2002, pp. 14-17.

7 Polnoe sobranie russkikh letopisei (henceforth - PSRL), II (Moscow, 1962, repr. 1998), col. 735-736. 
at a fair distance from main trade routes and rather difficult to access. The situation changed considerably in the first half of the thirteenth century, when crusaders from the West arrived in present day Latvia and Estonia and when Tatars devastated Rus'. ${ }^{8}$ The challenge of crusaders, the decline of Rus'ian power presented a good opportunity for Lithuanians to find their proper place under the sun.

By the early thirteenth century Lithuanian war-lords took part in the political game that was played in this part of Europe. The strongest relations they established were those with Polotsk and Galich-Volyn'. While the first principality tended to become absorbed within Lithuanian sphere of influence, the latter was quite another thing. Despite problems that came to surface with the death of duke Roman Mstislavich $(\uparrow 1205)$ it remained a vigorous polity which was bound to achieve its peak of flowering with Roman's son Daniil of Galich $(\uparrow 1264)$. But before he got the upper hand over his competitors Daniil was in need of allies, including Lithuanian warbands that were only too happy of the opportunity to pillage. Such activities were not only test for martial prowess, they also helped Lithuanian leaders become more aware of how international politics must be conducted and what political constellations were then present in this corner of Europe. ${ }^{9}$

Mindaugas came to occupy a dominant position among Lithuanian dukes in the $1240 \mathrm{~s}$. How he succeeded is not clear. The Chronicle of Galich-Volyn' informs us that he started hostilities with his kin, some of whom were either killed or expelled from Lithuania. ${ }^{10}$ Such a statement led some historians to equate the methods

${ }^{8}$ A good introduction to crusading in the Baltic is to be found in E. Christiansen, The northern crusades: the Baltic and the Catholic frontier 1100-1525 (London, 1980). Various theories on impact of Tatar invasion of Rus' are discussed at length by D. Ostrowski, Muscovy and the Mongols. Cross-cultural influences on the steppe frontier 1304-1589 (Cambridge, 1998).

${ }^{9}$ Thirteenth-century Lithuano-Rus'ian relations are discussed in detail by H. Paszkiewicz, Jagiellonowie a Moskwa, vol. 1: Litwa a Moskwa w XIII i XIV wieku (Warsaw, 1933), and in his The origin of Russia (London, 1954). V. T. Pashuto's book (Obrazovanie litovskogo gosudarstva (Moscow, 1959)) is useful as a compendium of facts that are placed in the strait-jacket of Marxist theory which sometimes betrays more post-1945 Bolshevik fears than represents thirteenth-century situation (Cf. S. C. Rowell, Lithuania ascending. A pagan empire within EastCentral Europe, 1295-1345 (Cambridge, 1994), p. 290). As for social history, the work by H. Łowmiański, Studia nad poczatkami społeczeństwa i państwa litewskiego (Vilnius, 1931-1932, 2 vols.) is still unsurpassed.

${ }^{10}$ PSRL, II, col. 858. 
employed by Mindaugas at consolidating his power with those of Clovis or the Merovingians in general. ${ }^{11}$ The stress on violence is plausible but this should not be ascribed to Mindaugas alone. Even so partisan a source as the said chronicle cannot conceal the fact that Mindaugas took over the possessions of his nephews, Tautvilas and Gedvydas, because of mutual enmity. ${ }^{12}$ They were given opportunity to go to Rus' to carve out land for themselves. After initial success they suffered defeat at the hands of Suzdal' dukes in 1248. ${ }^{13}$ Still worse, Mindaugas then tried to put them to death but they managed to escape. The failure of Mindaugas in doing this prompted them to seek asylum with Daniil of Galich who had married their sister. ${ }^{14}$ Mindaugas asked him to kill his enemies. This was, of course, denied, and then Daniil sent his messengers to Polish dukes asking for their help: it was a proper time for the Christians to deliver a coordinated blow at the pagans. Although Polish help was unforthcoming, Daniil managed to gather a conspicuous array of allies: the bishop of Riga, the master of the Teutonic Order in Livonia, tribesmen from Žemaitija (the westernmost part of Lithuania) and Yatvingia (south-west of Lithuania). Mindaugas was thus encircled by his enemies. After the first attacks from the south led by the Rus'ian dukes, the brethren of the Teutonic Order in 1250 managed to penetrate deeper into Lithuania than ever before or after. The devastation caused to Mindaugas and his allies by these raids prompted him to seek the way out of this awkward situation by trying to win over the Livonian master Andreas von Stirland. The Master did not let Mindaugas' proposals fall on deaf ears. The antiMindaugas coalition began to crumble and now new horizons were open to Mindaugas through the good offices of the Livonian Order. The Teutonic knights supported Mindaugas in beating back the last most serious attack of his enemies. Early in 1251 Mindaugas was baptised into the Catholic Church. The Pope became accessible to Mindaugas more than ever before. ${ }^{15}$

11 J. Latkowski, Mendog król litewski (Cracow, 1892), pp. 22-23; Z. Ivinskis, Lietuvos istorija iki Vytauto Didžiojo mirties (Rome, 1978; repr. Vilnius, 1991), pp. 162-163; cf. E. Gudavičius, Mindaugas (Vilnius, 1998) p. 177.

12 PSRL, II, col. 815: vrazhboiu bo za vorozh'stvo.

${ }^{13}$ PSRL, I, (St Petersburg, 1846), p. 201.

${ }^{14}$ PSRL, II, col. 815.

${ }^{15}$ All these vicissitudes of internal strife in Lithuania in which its neighbours were also embroiled have recently been discussed in Gudavičius, Mindaugas, pp. 211-227. 
The Royal Crown Mindaugas established contacts with Pope Innocent IV in 1251. The pope received his envoys in Milan and showed his great benevolence to Mindaugas. The news was good: a ruler in the far east of medieval Christendom received baptism. On this occasion the pope issued six documents that show how it was planned to introduce Christianity into Lithuania and how the law of nature must be supplanted by the law based on divine authority. Acceding to Mindaugas' own request the pope declared Mindaugas a special son of the Church, and took him, his family and his possessions under papal protection. ${ }^{16}$ The bishops in Livonia were obliged to keep an alert eye so that no one would dare to trouble the rule of Mindaugas as long as he remained faithful to the Holy See. ${ }^{17}$ Moreover, they had to support him in propagating the Faith among pagans. At last the pope comes to the most crucial issues. The bishop of Kulm (Chełmno in Poland), Dominican friar, Heidenreich, was entrusted with crowning Mindaugas and was empowered to consecrate a suitable candidate as the bishop of Lithuania. ${ }^{18}$ The latter was to be directly subordinated to the pope. Thus the pope prepared ground for two institutions that were useful to any independent state of medieval Europe: a royal crown and the ecclesiastical province. There was a good beginning for the new Christian state to be built. In 1253 Mindaugas received a royal crown and the priest brother of the Teutonic Order, Christian,

${ }^{16}$ VMPL, I, nr. 102, p. 49.

${ }^{17}$ Ibid., nr. 103, p. 49; nr. 106, p. 50.

${ }^{18}$ Ibid., nr. 105 , p. 50.

19 These matters were discussed extensively by Z. Ivinskis, 'Mindaugas und seine Krone', Zeitschrift für Ostforschung, 3 (1954), pp. 360-386 and M. Hellmann, 'Der Deutsche Orden und die Königskronung des Mindaugas', ibidem, pp. 387-396.

20 The efforts at evangelizing are mentioned in Livländische Reimchronik (henceforth $-L R$ ), ed. L. Meyer, Paderborn, 1876, lines 3569-3572; 3598-3601 (There is an English translation of this chronicle: J. G. Smith, W. L. Urban, The Livonian rhymed chronicle, Bloomington, 1977). Already in 1251 bishop Heidenreich received order from the Pope to take care of building the cathedral church (VMPL, vol. 1, p. 50, nr. 105), but this work seems to have been too difficult to implement and this is still one more indication that the Catholic Church in Lithuania then functioned only as a missionary Church. The literature discussing the problem of presumed Mindaugas' cathedral may be found in R. Mažeika, 'When Crusader and Pagan agree: conversion as a point of honour in the baptism of King Mindaugas of Lithuania', Crusade and conversion on the Baltic frontier, ed. A. V. Murray, (Aldershot, 2001), pp. 207-208. 
became bishop of Lithuania. ${ }^{19}$ Endeavours were made to evangelize the newly-converted people and the cathedral church was anticipated to be founded. ${ }^{20}$

Mindaugas did not receive the support from the Livonian Order gratis. He had to reciprocate with land grants to the Order. ${ }^{21}$ These donations were made in Žemaitija, in a land that was not controlled by the king. Similarly the bishop of Lithuania was granted such lands where only once could he try to set his foot. The itinerant king could hardly provide anything better in a society that still lived without paying taxes and largely free of the burden of administration. Parchment could easily bear what was too difficult to implement. Similar is the story of the expectations on the part of the papacy in respect of Lithuania.

The middle of the thirteenth century was uneasy time, when Europe lived under the threat of Tatar invasion. The pope took care of developing defensive measures. That is why the emergence of a Catholic ruler close to Orthodox Rus' and relatively not so far from the Tatars increased Mindaugas' value in the eyes of the pope. Similar hopes were entertained by the pope in respect of Daniil of Galich who, in the same year as Mindaugas, was crowned by a legate of Innocent IV. The pope had for some time vainly called for a crusade against the Tatars. But one military action measured against them did indeed take place in 1255. Mindaugas and Daniil decided to cooperate in their anti-Tatar effort which ultimately must have led, as Mindaugas indicated himself, to the capture of Kiev. The coordination between their troops was, however, poor and even led to mutual clashes. ${ }^{22}$ Such a failure must be accounted for a lack of confidence between the two kings. This is not surprising taking into account that they were after all competitors in power struggle within Rus'. Perhaps the surprise may be caused by simple daring on the part of Mindaugas: the ruler who had only recently survived due to external help thought of reaching out as

21 These donations are published in Liv-, Esth- und Curländisches Urkundenbuch, I, ed. F. G. von Bunge (Reval, 1853, repr. Aalen, 1967). Their authenticity has been rather hotly debated in earlier times and although now the majority of them may not be regarded as simple fakes this problem will always remain complicated not least because these donations are known only from the transcripts that were made at the end of the fourteenth century. The most serious study in these documents is K. Maleczyński, 'W sprawie autentyczności dokumentów Mendoga z lat 1253-1261', Ateneum wileńskie, 11 (1936), pp. 1-56.

${ }^{22}$ PSRL, II, col. 838-840. 
far as Kiev. This is an indication that he tried to take up seriously the role of a Christian king.

Innocent IV in his letters addressed to Mindaugas did not speak about such self-evident tasks of secular rule as preserving peace and keeping justice within the realm. Such tasks were put down that were somewhat more specific and perhaps more understandable to the addressee. Mindaugas had to propagate the Faith by expanding his domains at the expense of neighbouring pagans. Such missionary purposes for the new kingdom were still more reinforced when pope Alexander IV confirmed the already occupied Rus'ian lands to Mindaugas and his expansion into Rus' treated as conducive to the propagation of the Catholic Faith among the Orthodox (see the text of the second bull at the beginning of this article).

Although these two bulls, issued by the pope, Alexander IV on 6 March 1255, deal with matters affecting different internal and external affairs, they have something more in common than their rendering in clichés from the papal curia. First the pope allows Mindaugas to crown his would-be heir, and then confirms his acquisitions in Rus'. These cases can characterise the aspirations of Mindaugas and will allow us to see what the final outcome was.

The decision of Mindaugas to crown his son (whose name was probably Ruklys) indicates that Mindaugas wanted to see his Catholic heir on the Lithuanian throne and such a scenario can hardly be regarded as commonplace taking into account that Lithuanian paganism was then no less vigorous than that of Western Europe in the Early Middle Ages. The new faith always caused anxiety in society that was used to live according to ancestral traditions. Such a situation made it advisable to think of precautionary measures. It may be typified by some newly-converted kings in the British Isles who managed to provide themselves with a safeguard by keeping their children unbaptised at least for some time. Such a measure would allow to preserve the throne in the hands even of a pagan member of the ruling family if this would have been dictated by pagan reaction. ${ }^{23}$ In contrast, Mindaugas burnt the bridges behind him by nominating his Catholic son to be his heir. This step was intended to start the Catholic succession of Lithuanian kings. As the author of Descriptiones terrarum informs us Mindaugas received his regnum

${ }^{23}$ A. Angenendt, Kaiserherrschaft und Königstaufe. Kaiser, Könige und Päpste als geistliche Patrone in der abendländischen Missionsgeschichte (BerlinNew York, 1984), pp. 179-181. 
from the Roman see and enjoined his heirs to recognize the same. ${ }^{24}$ At the same time we must qualify this step by drawing our attention to the fact that this measure seems likely to be done not so much in defiance of possible pagan reaction but rather to prevent the succession by Vaišvilkas, a senior Orthodox son of Mindaugas. Once again uneasy situation between the Catholic and Orthodox worlds comes to the foreground.

As is indicated above, Lithuanian raids into Rus' was a usual phenomenon and they paved the way for Lithuanian expansion. Mindaugas tried to do the same what pagan Lithuanian grand dukes did much more successfully in the fourteenth century when Lithuania expanded over much of present day Belarus, Ukraine, and some part of Russia. ${ }^{25}$ Pagan dukes did not try to change the Rus'ian way of life and their sons destined to rule in Rus' adopted as a rule the Orthodox faith thus becoming 'natural' to their new environment. Mindaugas was too weak to do something more than usual raids, but he at least used slogans that could be appreciated within Catholic circles. His collaboration with the papacy and the Teutonic Order, and his bid of 1255 against the Tatars was something what could hardly escape their notice. In 1258 the Tatar military leader Burunday turned his hordes against Daniil and Galich-Volyn' succumbed to demonstration of Tatar power. The Rus'ians were compelled to take part in Tatar onslaught on Lithuania in 1258-1259. This was the beginning of the end of the Lithuanian Catholic kingdom. The pope began to talk about the destruction of Lithuania. ${ }^{26}$ The situation after the blow delivered at the hands of Tatars was further complicated by a signal victory which Žemaitians achieved over the Teutonic knights from Prussia and Livonia at the battle of Durbe (July $13,1260) .{ }^{27}$ Due to these events the power base of Mindaugas

${ }^{24}$ M. L. Colker, 'America rediscovered in the thirteenth century?', Speculum, 54 (1979), p. 722: Hec habet etiam ad orientem conterminam Ruscie terram Lectavie. Cuis rex primus Mendogus baptizatus est et in coronacione sua me ibidem existente regnum suum a sede Romana recipiens hoc idem reliquid suis posteris faciendum dummodo eandem ad huiusmodi factum curam adibeant diligentem.

25 On Lithuanian expansion into Rus' see Rowell, Lithuania ascending, pp. 82-117.

${ }^{26}$ Preussisches Urkundenbuch, I, 2, ed. A. Seraphim, (Königsberg, 1909), nr. 111 and nr. 112, p. 102.

27 See for example Chronicon terrae Prussiae of Peter of Dusburg in Scriptores rerum prussicarum, I, (Leipzig, 1861), pp. 96-97. 
began to crumble. Treniota, son of Mindaugas's sister, began to nourish greed for power and established contacts with pagan Žemaitians who were very interested in driving Mindaugas apart from his Teutonic allies, in which they succeeded in $1261 .{ }^{28}$ The old pretender Tautvilas, who then ruled Polotsk, seems to have begun to conspire against Mindaugas as well. It looks likely that in this time Mindaugas' son Vaišvilkas finally came over to the camp of Daniil of Galich and became an Orthodox monk. ${ }^{29}$ The opposition to Mindaugas was agitated when, according to the GalichVolynian Chronicle, he maltreated duke Daumantas, future Orthodox St. Dovmont-Timofey ( $\uparrow 1299)$, by taking his wife after his own beloved wife Martha had been dead in $c$. 1262. The conspirators managed to pick up a chance and swiftly kill Mindaugas and two his sons Ruklys and Rupeikis in autumn $1263 .{ }^{30}$ Thus the royal branch of Lithuanian rulers was severed for ever.

The blood-bath initiated by the murder of Mindaugas continued. Both Treniota and Tautvilas aspired to sit on the throne at the expense of each other. Treniota was more swift and Tautvilas soon departed this life. Within a year Treniota was killed by the servitors of Mindaugas. ${ }^{31}$ His demise opened the way for Vaišvilkas who by revenging on his father's enemies also paved the way for the rule of Rus'ian dukes in Lithuania. Having acknowledged their superiority after three-year suspension of monastic vows he returned to monastery and bequeathed his throne to Daniil's son Shvarn who had married his sister. Shvarn did not manage to consolidate his power in Lithuania and was ousted by the energetic pagan Traidenis who in $c .1270$ became the undisputed leader of Lithuania. ${ }^{32}$

These seven years after the murder of Mindaugas have buried almost everything what could have anything to do with Catholic Lithuania. Even the memory of Mindaugas himself evaporated from local tradition and only external evidence in a form of German and Rus'ian chronicles, papal writs and something very little else, allows

${ }^{28}$ This scene is graphically depicted in $L R$, col. 6334-6470.

${ }^{29}$ An outline of his political career and an in-depth study of his post mortem life in Rus'ian historiographical and literary sources are presented by D. M. Goldfrank, 'The Lithuanian prince-monk Vojšelk: a study in competing legends', Harvard Ukrainian Studies, 11, (1987), pp. 44-76.

${ }^{30}$ PSRL, II, col. 860.

${ }^{31}$ Ibid., col. 860-861.

${ }^{32}$ Ibid., col. 862-863, 867-869. 
us to try to look in his distant and dim epoch. During the reign of Mindaugas Lithuania had a chance of becoming part of medieval Latin Christendom, but ultimately remained within Eastern Europe together with Rus'ians and Tatars. The law of succession as it was anticipated by Mindaugas and his clerical advisers would probably have made the central authority more stable. Instead, fourteenthcentury successions betray similarity to those of Kievan Rus' when side-branches of the ruling family nourished claims even to the throne. ${ }^{33}$ The expansion of Catholic Lithuania would not have been, almost certainly, so conspicuous as that of pagan Lithuania in the fourteenth century, but perhaps it would have gained more in terms of integration, which was an invaluable asset by the early sixteenth century when Russia came to collect what once belonged to Kiev. Much of what Mindaugas had done or aspired to be done was either destroyed or implemented only partly at best. To a huge degree this must be ascribed to the fact that the Christian faith did not take deep root within the ruling elite.

${ }^{33}$ Cf. S. Franklin, J. Shepard, The Emergence of Rus 750-1200, (LondonNew York, 1996), p. 191-193. 